He now adds that he might as well "have used any of the other cases collected by Mr. Darwin." It is not a very material point, but $I$ do not find that Mr. Darwin makes any reference to Wells's theory in his discussion of correlation, nor do I see any in the body of the sixth edition of the "Origin of Species" "though a passage is quoted from Wells's paper at p. xi. of the " Historical Sketch" which is prefixed to it. It had, however, independently occurred to Mr. Darwin, and he discusses it in a somewhat different connection in the "Descent of Man" (i. pp. 242-245). He remarks:- "That the immunity of the negro is in any degree correlated with the colour of his skin is a mere conjecture ; it may be correlated with some difference in his blood, nervous system, or other tissues." And he concludes :- "I endeavoured with but little success to ascertain how far it held good." Elsewhere he gives cases to show that "differences in colour are correlated with constitutional differences." But these, though interesting, seem to me too obscure to found any definite conclusion upon. And no attempt is made to show on what material basis, subject to variation, the constitutional difference depends.

The correlation principle as originally defined dealt then with obvious and measurable characters. It is extended by Prof Lankester's "suggestion" to what is obscure, may be unknown, and perhaps unknowable. In considering the probable utility of any specific character we shall, if the extended principle be accepted, be always open to the objection that we cannot show that the character is not the outward and visible sign of some unobservable internal peculiarity. But that is a position which I do not think we are bound to accept till something more than a hypothetical case has been established.

To sum up: Mr. Darwin based the correlation principle on what is concrete and tangible; Prof. Lankester extends it to what is intangible and hypothetical. It is not a question of what is " apostolic and orthodox," but of what is susceptible of reasonable proof.

As I do not propose to continue this discussion any further, I will take the opportunity of saying that $I$ think it is a matter for regret that, as Prof. Lankester was present at the meeting of the Royal Society when Prof. Weldon's paper was read, he did not deliver himself on that occasion of his somewhat belated criticism. Prof. Weldon's work is of extraordinary interest, and one cannot but admire the self-sacrifice with which such laborious investigations have been prosecuted. If they want a defence, I think the following passage from the "Origin of Species" supplies it.

"It may metaphorically be said that natural selection is daily and hourly scrutinising, throughout the world, the slightest variations; rejecting those that are bad, preserving and addino up all that are good; silently and insensibly working, whenever and zeherever opportunity offers, at the improvement of each organic being in relation to its organic and inorganic condition of life. We see nothing of these slow changes in progress, until the hand of time has marked the lapse of ages, and then so imperfect is our view into long-past geological ages, that we see only that the forms of life are now different from what they formerly were." (Sixth edition, pp. 65-66.)

I do not myself see how the slow and ordinarily imperceptible, but inevitable action of natural selection can be demonstrated except by the statistical method. But, firmly as I believe in the inevitableness of that action, I confess that the results attained by Prof. Weldon surpassed my expectations. I am unable to agree with Prof. Lankester, that the investigation does not satisfy the canons of scientific inquiry. The hypothesis on which it appears to me to be based is, that the mean configuration of any organism at any moment is an optimum. In order to test that by the statistical method, the choice of measurements is a mere matter of convenience.

Kew, August 29.

Thermometer Readings during the Eclipse.

I STARTED on July 30 in the King Harold, and arrived at Vadsö on August 6 . On board this vessel, amongst others, were Prof. Rambaut and Dr. Hugh R. Mill, of the Geographical Society, who I see has sent a note which appears in NATURE of August 27 , as to some observations of temperature he took during the eclipse. I was constantly with Prof. Rambaut on the island at Vadsö, and he particularly requested me to observe the temperatures of sun, and shade thermometers during the eclipse at the position he had taken for his observations, which were specially directed to the degree of polarisation of different parts of the corona. I enclose a diagram of my observations, which Prof. Rambaut has suggested I should send to NATURE, should you think they are worth recording. The fall of the sun thermometer (which unfortunately was fully shaded by cloud) was, from $4 \mathrm{~h}$. Iom. to just after totality, $2^{\circ}$, and its recovery

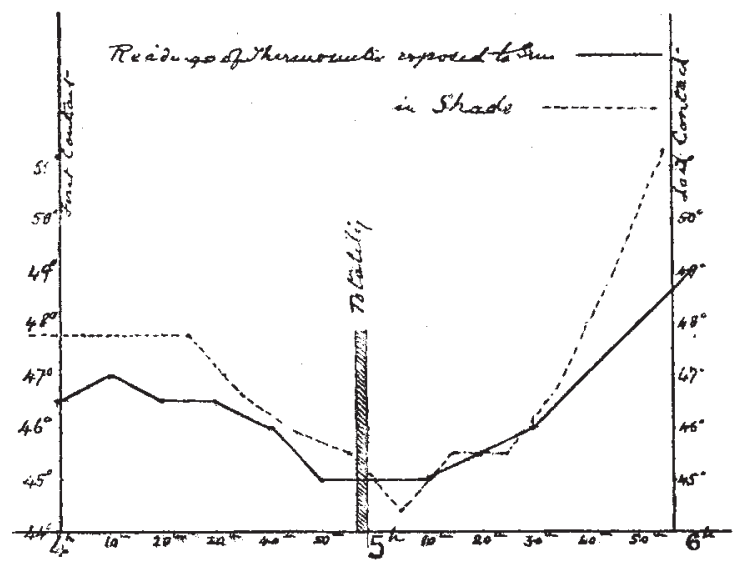

Diagram of observations of sun, and shade thermometers during the: eclipse of the sun, August 9, taken at Vadsö.

from that point to $5 \mathrm{~h} .56 \mathrm{~m}$., last contact, was $3^{\circ} \cdot 6$. The shade thermometer showed greater variations, viz. a fall of $3^{\circ} \cdot 35$, and subsequent rise at $5 \mathrm{~h}$. $5 \mathrm{om}$. of $5^{\circ} \cdot 6$.

8 Devonshire Place, W., September 3.

H. Wollaston Blake.

\section{Sailing Flight.}

Mr. Peat. (NaTURe, vol. liv. p. 3I7) having again brought up this matter for discussion in the columns of NATURE, I would like to make a new suggestion concerning it, which I have long had on my mind. It will be remembered that Lord Rayleigh (NATURE, vol. xxvii. p. 534) assumed an increase of wind-velocity with altitude to explain the facts of circular soaring, and that quite recently Langley (Amer, Joum. Sci., vol. xlvii. p. 4r) has tried to explain the same phenomenon by the assumption-supported in his case by direct observationthat the velocity and direction of the wind is subject to great and rapid changes. Concerning this latter statement, I must say that although in a thunderstorm great irregularities can be observed in the upper air-currents, the shape and relative constancy of small clouds in fine weather seem to show that under ordinary conditions the upper air-currents are much steadier than Langley assumes, and that, therefore, soaring birds can by no means always depend on the presence of wind-irregularities sufficiently great to sustain them. Although no doubt windvelocities generally increase with altitude, I do not believe that such an increase will always be present, nor that it will, when present, be usually sufficiently great to produce the force necessary for raising a bird. We observe, however, that birds do soar nearly always, perhaps even more frequently in fine weather, when the currents are more steady, than in rough weather, when they are more irregular.

Under these circumstances it seems to me that neither Lord Rayleigh's nor Langley's assumptions concerning the source from whence these birds derive the power of overcoming gravity can be correct. It seems to me, doubtless, that a steady horizontal wind of equal velocity in different altitudes does enable them to soar and to rise. It is remarkable that this soaring without loss of elevation is always accompanied by circling. Elevation is not known to occur without circling, as it might if Langley's views were correct. Were the bird attached to the earth by a string like a kite, it could be and, if the wingplanes were placed in proper positions, would be sustained and raised by a purely horizontal and steady wind. Now it seems to me that the circling replaces the string. A circling top retains its position on account of the force in its rapidly circling parts. Could not the soaring bird produce-through circling-a similar stability which, acting like a kite-string, would enable it to oppose itself to the wind, and thus convert the horizontal wind-force partly into a vertical, lifting force? Mr. Peal, in his last letter $\left(l_{.} c_{*}\right)$ very correctly remarks that the connecting- 
line of the wing-tips does not lie horizontally, but obliquely, so as to describe in moving, a cone, apex downward. This slant gives, through the resistance of the air, a certain degree of rigidity to the system represented by the soaring and circling bird, which corresponds to the rigidity that holds the parts of the top together, and prevents them from flying off in tangents.

Being myself a zoologist, and not a mathematician, I cannot venture to state this hypothesis otherwise than in the shape of a question; perhaps one of the mathematical readers of NATURE will kindly take the trouble to answer it.

Czernowitz, August 23.

R. VON LENDENFEI.D.

\section{THE CONWAY EXPEDITION TO SPITZBERGEN.}

THE expedition organised by Sir Martin Conway for the exploration of the interior of Spitzbergen left London on June 2 , and first sighted the island on June 17, the exact tercentenary of its discovery by Barentz. The northern ice sheet having broken up exceptionally early this year, the floes off the western coast of Spitzbergen were unusually heavy, and somewhat delayed the arrival in Advent Bay. The expedition landed the stores there on June 20 . In accordance with the plan of operations arranged, the members divided into two parties: one party, consisting of Sir Martin Conway, Mr. E. J. Garwood, a well-known geologist and Alpine photographer, and the writer, proceeded to cross Spitzbergen to the east coast. The other party, composed of Mr. Trevor Battye, the ornithologist with the expedition, and Mr. H. E. Conway, the artist, cruised about Ice Fjord and its two chief bays, in order to collect birds and make sketches.

Till the present year very little was known of the interior of the country. The coasts have been carefully surveyed by many expeditions, of which those of Parry and of various Swedish explorers, notably the series organised by Baron Nordenskiöld, are of the first importance. But hitherto the only contributions to our knowledge of the interior were those of the late Gustav Nordenskiöld and M. Rabot. The former marched for three days across the ice-sheet from Hornsund to Bel Sound, along a line parallel to the west coast and some miles inland. M. Rabot made a three days' excursion up a valley going inland from the head of Sarsen Bay. With these exceptions, exploration had been limited to the coast, and to within a day's march of it. Sir Martin Conway therefore took out two ponies and sledges, with which to provision some inland camps. The ponies answered well, but the sledges broke down repeatedly, and thus greatly delayed progress.

The principal geographical work of the expedition was the first crossing of Spitzbergen, from Advent Bay to Agardh Bay. The country traversed was mapped by Sir Martin Conway, while his two companions worked out the geology of the country and made collections of its flora and of its very limited fauna. Subsequently the whole expedition sailed northward to the Seven Islands, and through Kinlopen Strait and across Olga Strait to near King Charles' Islands. An effort to complete the circumnavigation of Spitzbergen was nearly successful, but failed owing to the passages into Sta Fjord being blocked by fast ice. Mr. Garwood and Mr. Battye ascended Hornsund Sind, the highest peak in Spitzbergen.

In regard to the biological results, it is too early to estimate their value, for novelties can only be expected among the invertebrates, which have not yet been examined. The only land mammals are the bear, arctic fox, and reindeer, of which the last are abundant. Birds are individually numerous, but the species are few ; of the twenty-five authentically recorded species, we saw all but the snowy owl (Nyctea nivea). One addition to the list might have been made, had we been able to carry a gun across the island; for we saw an unrecorded species on the shore of Agardh Bay. Several dredge hauls were made in Advent Bay and Hornsund, yielding various species of worms, mollusca, crustacea, ophuiroids, \&c.

Botanical collections were mate during the traverse of the island in order to contrast the flora of the inland valley, of the high plateaus, and of the nunataks, with that of the coast. The flora is remarkably uniform, and the influence of height has less effect than those of situation and season. The species found on the mountain summits in the middle of the summer were the same as those found on the coast at the beginning of the spring. As the season advanced the species first found in flower on the lowlands and in sheltered valleys were succeeded by another set ; but at any time it was only necessary to seek exposed and barren positions, or to climb above the snow line, to find the first flora still in flower.

Spitzbergen offered better opportunities for geological than for either zoological or botanical work. The rock sequence includes representatives of the Archæan, Lower Palæozoic, Devonian, Carboniferous, Trias, Jurassic, and Middle Tertiary. The coast series has been described by many workers, including Keilhau, Torell, Loven, Lamont, Nordenskiöld, Nathorst, de Geer, and others; but as the interior had not been visited, we had there a fresh field of work. In this I had the good fortune of the co-operation of $\mathrm{Mr}$. E. J. Garwood; together we mapped the belt of country between Advent Bay and Stor Fjord, and made collections from each of all the geological systems that occur in Spitzbergen. Our work was greatly facilitated by the simplicity of the geology of the country; the sections are numerous and clear, and the structure is often shown with diagrammatic clearness.

Our best opportunity for the study of the Archaan rocks was given by the bare cliff sections at Walden Island, one of the Seven Islands situated in lat. $80^{\circ} 38^{\prime}$. Here we found that this series was formed of a group of schists which have been invaded by two sets of intrusivegneisses; great blocks and seams of the schists are included in the gneisses, while veins from the latter cut upward into the schists.

The general stratigraphical sequence has many points of interest. Great stress is often laid on the absence from Spitzbergen of any indication of glacial action in times earlier than the Pleistocene; and also on the fact that the occurrence of fossil coral reefs, and beds containing warm, temperate, or even sub-tropical plants, shows that the climate before the Pleistocene epoch was quite different from that of the present time. Our evidence, however, greatly simplifies the task of explaining these difficulties; that remarkable changes of climate have happened, is unquestionable. One such is probably in progress still. But these changes of climate are reduced to much narrower limits than seenıs to be generally considered. We found signs of glacial action in the deposits of, at least, two different eras before those of the "great ice age." Moreover, the so-called coral reefs are not coral reefs, and might have been formed in the adjoining seas; and the fossil plants do not indicate so mild a climate as those of the Miocene beds of Southern Greenland. In fact, the whole of the fossil faunas and floras. from the Devonian onward are comparatively poor in species, and appear to have lived under unfavourable conditions, and their existence in Spitzbergen may all be explained by the assumption of only a sub-arctic climate.

One of the main temptations Spitzbergen offers to the geologist is a magnificent opportunity for the study of glacial action; for we may see there marine and land ice working side by side. As our time on the coast was short, we naturally saw most of the inland glaciers. These are very different from those of Switzerland; for example, they have practically no névé fields. All the snow that falls on the collecting-ground at the head of the glacier turns to ice in situ. Time after time we ascended glaciers, expecting to be soon stopped by

NO. I 4O2, VOL. 54] 